Western University

Scholarship@Western

Aboriginal Policy Research Consortium International (APRCi)

$1-2012$

\title{
Utilising Indigenous seasonal knowledge to understand aquatic resource use and inform water resource management in northern Australia
}

Emma Woodward

Sue Jackson

Marcus Finn

Patricia Marrfurra McTaggart

Follow this and additional works at: https://ir.lib.uwo.ca/aprci

Part of the Environmental Policy Commons, and the Other Geography Commons

Citation of this paper:

Woodward, Emma; Jackson, Sue; Finn, Marcus; and McTaggart, Patricia Marrfurra, "Utilising Indigenous seasonal knowledge to understand aquatic resource use and inform water resource management in northern Australia" (2012). Aboriginal Policy Research Consortium International (APRCi). 318.

https://ir.lib.uwo.ca/aprci/318 


\title{
Utilising Indigenous seasonal knowledge to understand aquatic resource use and inform water resource management in northern Australia
}

\author{
By Emma Woodward, Sue Jackson, Marcus Finn and Patricia Marrfurra McTaggart
}

\begin{abstract}
Emma Woodward, Sue Jackson and Marcus Finn are with CSIRO Division of Ecosystem Sciences (PMB 44 Winnellie, Northern Territory 0822, Australia; Tel: +618 89448409; Email: Emma.Woodward@csiro. au). Patricia Marrfurra McTaggart is a member of Nauiyu Inc. (PMB 28 Northern Territory 0822, Australia; Email: Merrepen@bigpond.com). This research is part of the Tropical Rivers and Coastal Knowledge (TRaCK) project 'Indigenous socio-economic values and river flows', which revealed seasonal patterns of Indigenous aquatic resource use, eco-bydrological dependencies of key harvested species, and the social, cultural and economic significance of these species to Indigenous communities and their economies.
\end{abstract}

\begin{abstract}
Summary Indigenous ecological knowledge can inform contemporary water management activities including water allocation planning. This paper draws on results obtained from a 3-year study to reveal the connection between Indigenous socio-economic values and river flows in the Daly River, Northern Territory. Qualitative phenological knowledge was analysed and compared to quantitative resource-use data, obtained through a large household survey of Indigenous harvesting and fishing effort. A more complete picture of Indigenous resourceuse and management strategies was found to be provided by the adoption of mixed methods. The quantitative data revealed resource-use patterns including when and where species are harvested. The qualitative Indigenous ecological data validated results from the quantitative surveys and provided insights into harvesting and resource management strategies not revealed by the discrete time-bound surveys. As such, it informed the scientific understanding of patterns of resource use and relationships between people, subsistence use and river flows in the Daly River catchment. We recommend that natural resource managers, researchers and Indigenous experts prioritise collaborative projects that record Indigenous knowledge to improve water managers' understanding of Indigenous customary aquatic resource use.
\end{abstract}

Key words: aquatic ecosystems, Daly River, Indigenous ecological knowledge, seasonal calendar, subsistence resource use, traditional knowledge.

\section{Introduction}

ndigenous people value aquatic ecosystems in a number of inter-related ways: they provide bush foods, art and craft materials and medicines; they are part of a socially and culturally significant freshwater landscape; and have the potential to sustain future water-related businesses and employment (Jackson \& Altman 2009). The customary rights of Indigenous Australians to natural resources have been accorded greater recognition by state management systems since the Mabo decision of 1992. In Mabo, the High Court recognised the entitlements of Indigenous people to their ancestral lands under their customary laws (Neate 2002). Notwithstanding this formal recognition, there has been relatively little quantitative research on the use of wild resources by Indigenous people in Australia (see Altman 1987; Gray et al. 2005; Venn \& Quiggin 2007) nor their customary water management systems (Yu 2003; Toussaint et al. 2005;
Jackson \& Altman 2009; Weir 2010; Finn \& Jackson 2011).

Indigenous ecological knowledge (IEK), also known as traditional ecological knowledge, refers to 'a cumulative body of knowledge and beliefs handed down through generations by cultural transmission about the relationship of living beings (including humans) with one another and with their environment' (Berkes 1993). It is widely understood to be integral to the management of many Indigenous customary land and water systems, including subsistence resourceuse strategies. Surveys of the literature on IEK emphasise the means by which it is transmitted and the longevity of its use; there is an emphasis on continuity and cumulative acquisition of knowledge generated by communities heavily reliant on natural resources. Knowledge is passed down through generations over many hundreds of years, although many authors stress its dynamic nature in response to populist images of traditional knowledge as static or unchanging (Berkes 1993; Goodall 2008).

There is increasing interest among scientists and government and nongovernment agencies in the potential for IEK to contribute to contemporary natural resource management (NRM) (Berkes et al. 2000; Huntington 2000; Prober et al. 2011). Such interest is stimulated in part by Indigenous people's concern about the rapidly attenuating local knowledge base (Langton 1998; Jackson \& O'Leary 2006; Luckert et al. 2007). Indigenous knowledge can be 'geographically and temporally more extensive' than research-based knowledge (Fraser et al. 2006), especially in regions where Indigenous livelihoods are reliant on natural resources, because of the relatively widespread and long duration of Indigenous occupation and observation. For this reason, studies of IEK are growing in popularity in current scientific endeavours, informing north Australian NRM (Russell-Smith et al. 1997; Horstman \& Wightman 2001; Ens et al. 2010; Hill 
et al. In press), and there have been a number of valuable ethno-biological studies of Indigenous subsistence strategies (Chase \& Sutton 1981; Meehan 1981; Altman 1987; Rose 1987; Walsh 1990; Buchanan et al. 2009).

However, Indigenous knowledge is not yet well incorporated into NRM (Finn \& Jackson 2011), and there have been calls for research to improve the uptake of IEK and to enhance its impact on NRM (Natural Resource Management Ministerial Council 2010; Prober et al. 2011).

In many parts of Australia, knowledge exchange between scientists and local communities has resulted in an improved understanding of Indigenous seasons (see for example Marrfurra et al. 1995; Rose 1996; Russell-Smith et al. 1997; Baker 1999; Yingguny Lindsay et al. 2001; Bradley 2010), and seasonal calendars have proved to be a widely popular representation of this knowledge for National Park interpretation, school science curriculum and for promoting general public awareness of IEK. More recently, renewed attention has been given to IEK events that correspond with the life cycle of food resources because of their relevance in the monitoring of impacts from environment change, particularly climate change (Turner \& Clifton 2009).

The need to understand how socio-ecological systems may be affected by water development is particularly pressing in the undeveloped catchments of northern Australia, given the demand for water resources from southern Australia (Petheram et al. 2008). A recent study sought to understand the socio-economic value of rivers and water to Indigenous communities in two northern catchments where water resource planning has recently begun, the Daly River in the Northern Territory and Fitzroy River in Western Australia. This study combined qualitative and quantitative methods to understand the spatial and temporal pattern of Indigenous resource use, its social, cultural and economic significance to local communities and their economies, and the eco-hydrological dependencies of the wild aquatic resources consumed by Indigenous households (Finn \& Jackson 2011; Jackson et al. 2011). The research project is one of 29 , involving over 70 socio-cultural, economic and biophysical researchers, which contribute to a research consortium known as Tropical Rivers and Coastal Knowledge (TRaCK) (http://track.gov.au/). This research hub aims to improve the science and knowledge available to support the sustainable use and management of Australia's tropical rivers

This paper discusses how IEK, particularly seasonal knowledge of resource harvesting and the environmental cues and indicators used to target specific species, provides insights into the resource management strategies of Indigenous people, strengthens the analysis of quantitative household survey data and identifies priorities for water planning and management.

This paper focuses on the results from the Daly River (NT) catchment and reports on two components of the larger socioeconomic project: (i) the qualitative documentation of IEK with a focus on the creation of a seasonal calendar of aquatic resource use and (ii) quantitative data collected through household surveys. Specifically, the paper focuses on Ngan'gi seasonal knowledge from the Daly River region of the Northern Territory. NonIndigenous researchers questioned Indigenous participants with ecological expertise, including the fourth author, about resource use and seasonal availability, leading to the development of the Ngan'gi Seasons calendar (see http://www.csiro.au/ resources/Ngangi-Seasonal-Calendar.html). The seasonal calendar reveals extensive phenological knowledge, including the observation of life-cycle changes in plant and animal species that indicate the timing of the onset of growth stages in aquatic resource species, linguistic references to these events, concepts of time as they relate to seasonal change, and spiritual beliefs about cause and effect of seasonal change (Lantz \& Turner 2003).

This paper presents a selection of data from the qualitative documentation of IEK and then compares a subset of IEK and quantitative resource-use data to illustrate the value in an aligned, complementary analysis of these data types. Finally, we discuss some of the relative strengths and weaknesses of each method of generating and gathering data on aquatic resource use and the utility of combining the two techniques.

\section{Methods}

\section{Study sites}

The project collected data from the remote Indigenous communities of Pine Creek and Naiuyu Nambiyu in the Daly River catchment (see Fig. 1). The majority of Indigenous people in north Australia live in remote locations that exist as centralised townships, commonly referred to as communities and homelands. Remote communities vary in size from an extended family group to over 2500 people (Brimblecomb 2007) with the Indigenous population of the two Daly River study sites ranging from approximately 120 to 370 people.

The Daly River catchment (Northern Territory) covers $53000 \mathrm{~km}^{2}$ and has a mean annual discharge of $6730 \mathrm{GL}$. The Daly River displays distinct hydrological

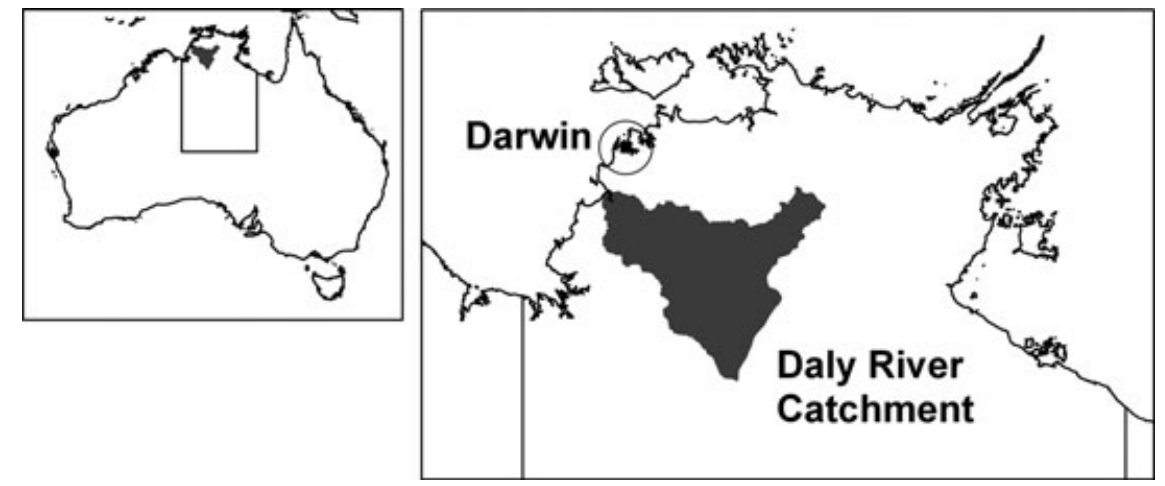

Figure 1. Map showing the location of the study site: Daly River catchment, Northern Territory, Australia. 
seasonality with most of its discharge occurring predominantly during the summer wet season (November to April, hereafter referred to as 'the Wet'), with high interannual variation in the magnitude and timing of peak flows (Kennard et al. 2010). During the winter dry season (May to October, hereafter referred to as 'the Dry'), the main channel of the Daly River is supplemented by groundwater inputs and is classified as perennial; however, its tributaries range from perennial to extremely intermittent.

Collation of local ecological knowledge was undertaken both in the community and in surrounding wetlands, while on hunting, gathering or fishing trips, allowing the researchers to learn through demonstration. The timing of documentation of seasonal information was integral to the compilation of the calendar where recollection of ecological indicators was stimulated by environmental cues. This necessitated repeat visits and proofing of calendar content over a period that spanned the full cycle of seasons (Woodward 2010)

The first of the four calendars created through the broader socio-economic project, the 'Ngan'gi Seasons', was initiated by the fourth author, a senior Ngan'gi language speaker from Nauiyu Nambiyu, Daly River. 'Ngan'gi' refers to two similar Aboriginal languages of the Daly River region, Ngan'gikurunggurr and Ngen'giwumirri (Reid \& Marrfurra McTaggart 2008).

Household surveys provided quantitative information on the spatial and temporal distribution of aquatic resource use. Twenty-four households, representing approximately $20 \%$ of the Indigenous population in the Daly River study communities, were repeatedly surveyed twice every 3 months over a 2-year period from 2008 to 2010 (for a full description of the survey methodology see Jackson et al. 2011). These data were used to assess the potential socio-economic impacts of flow alterations for Indigenous communities in the study areas. Detailed results from the survey data and the economic valuation are presented in the study by Jackson $e t$ al. (2011) and Finn and Jackson (2011).

\section{Results}

The Ngan'gi Seasons calendar, displayed as Figure 2, has four to five seasons that fall within the Wet and eight to nine seasons that fall within the Dry. A couple of the seasons fall into both the Wet and Dry categories. The cycle of seasons observed in

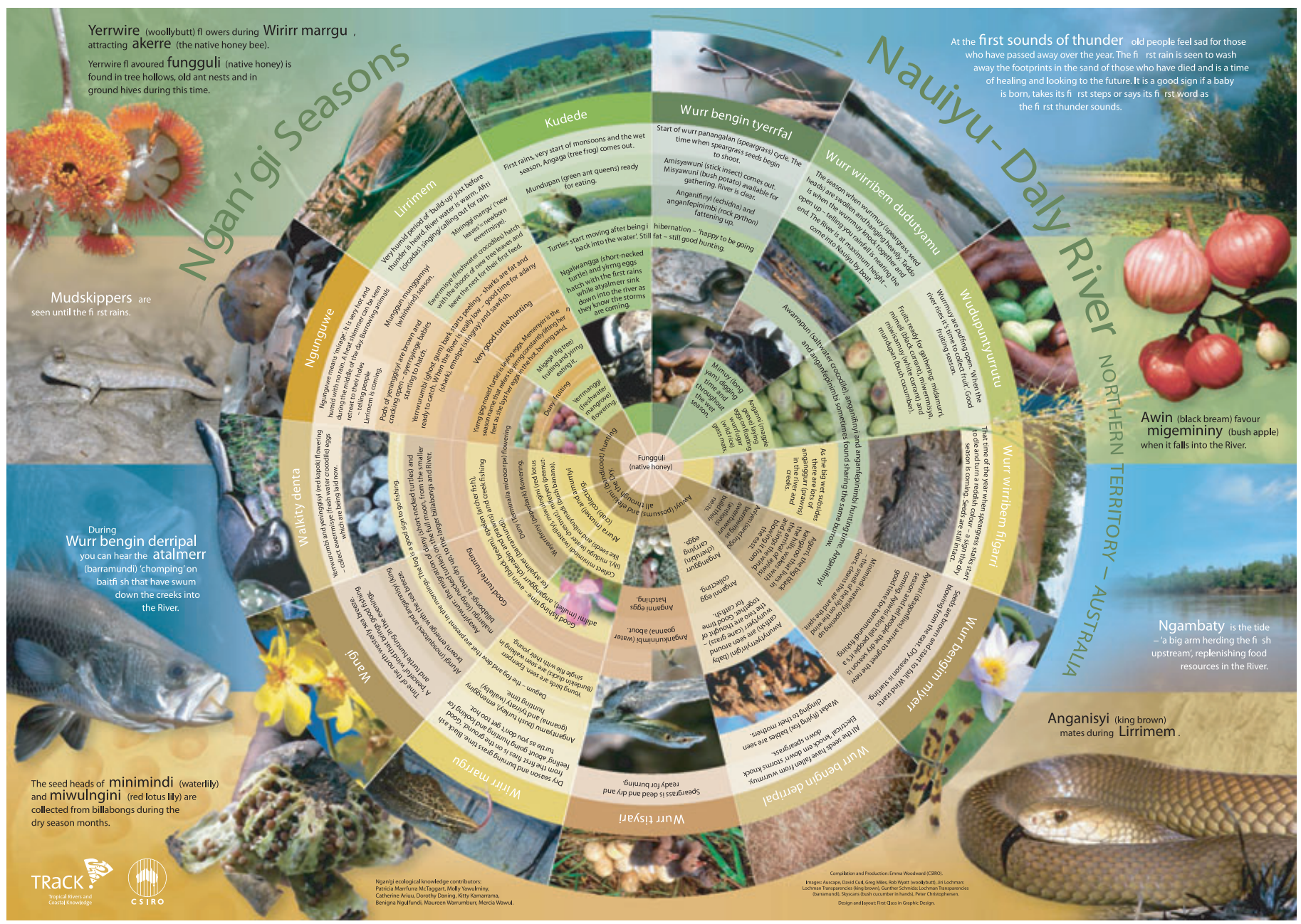

Figure 2. The Ngan'gi Seasons calendar. 


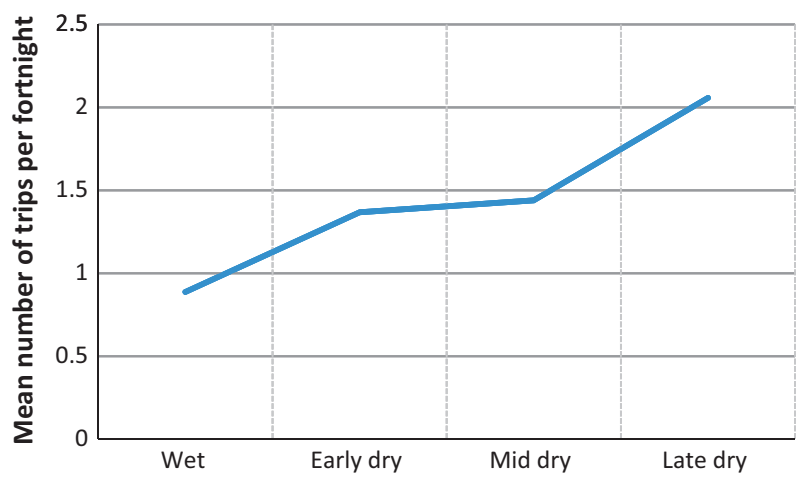

Figure 3. Patterns of resource harvesting of surveyed households in the Daly River, Northern Territory.

the Ngan'gi Seasons calendar is different to the seasons represented in the Gregorian calendar, with many of the Ngan'gi seasons named in accordance with the various life stages of the local dominant Wurr (Spear Grass, Sorghum intrans). Each of these seasons is said to occur once the phenological event has been observed.

During the Wet, Indigenous residents of Nauiyu have limited access to hunting sites owing to inundation, and animal species also disperse within the flooded landscape, making them more difficult to hunt. Lower availability of food resources during the Wet coincides with fewer reported phenological events and fewer distinct seasons for this time of the year. This observation is supported by the household survey data showing that the frequency of harvesting trips is at its lowest in the Daly catchment during the Wet (see Fig. 3).

According to the seasonal calendar, hunting and gathering of resources starts in earnest towards the end of the Wet, with the collection of fruits during the period known as Wudupuntyurrutu, after the river has risen following heavy rains. During this time Awarrapun (Saltwater Crocodile, Crocodylus porosus), Anganifinyi (Echidna, Tachyglossus aculeatus) and Anganfepinimbi (Rock Python, Liasis olivaceus) are also actively hunted.

The Dry is considered to be coming when Wurr stalks start to die and turn a reddish colour. At this time, the Wet is subsiding. This season is known as Wurr wirribem filgarri, the period when people actively hunt for Anganggurr (Freshwater Prawn, Macrobrachium rosenbergii) in the river and creeks. Household data support this observation, with $71 \%$ of Freshwater Prawns harvested in the Daly River taken during the Early Dry survey period.

Ngan'gi speakers know that the Dry has started when the wind blows from the east and Wurr seeds have turned brown and start falling to the ground. This season is known as Wurr bengim miyerr. It is $A y i$ wisi (dragonflies, order Odonata) that indirectly bring the wind in the early Dry, as their arrival wakes Agurri (the big Black Kangaroo, Petrogale brachyotis) that lives in the hills who then sings the wind, blowing it from the east. The dragonflies indicate to people that it is time to fish for Atyalmerr (Barramundi, Lates calcarifer) near the mouths of small creeks. This seasonal observation by Ngan'gi speakers is clearly reflected in the household survey data which reveal that Barramundi harvesting success peaks in the Early Dry (see Fig. 4).

Wurr bengin derripal is a season name that, according to the fourth author, literally translates to 'it's knocked the grass into a bent over position'. This period therefore refers to the time of the year when storms push the Wurr over. Rain is still falling, and it is a good time to harvest the eggs of Anganni (Magpie Goose, Anseranas semipalmata) as there is still a fair amount of water around to support the floating nests. This time of the year is known to be good for catfish (Arius spp.), but is not yet time for hunting other fish. This time might be thought of as the Late Wet/Early Dry season.

Resource collection markedly increases with the arrival of Wirirr marrgu. At this time, the Dry is in full-swing, and the Spear Grass is being burnt and black ash is on the ground. People are clearly influenced by the temperature and humidity, and they report having a 'good feeling' about going hunting for turtles (Carettochelys insculpta; Chelodina rugosa; Emydura spp.; Elseya spp.) at this time because it isn't too hot. It is now time to fish for Awin (Black Bream, Hephaestus fuliginosus), Epelen (Archer Fish, Toxotes chatereus), Adilmi (mullet, Liza spp.) and freshwater Prawns and to target Barramundi living in the creeks. The results from the household surveys show that the greatest numbers of Black Bream were harvested in the Early Dry and Mid Dry survey periods (Jackson et al. 2011). Billabong levels have dropped significantly since the beginning of the Wet, so a range of lilies and other water-dependent plants can now be accessed along the margins of billabongs and swampy areas. Water-dependent plant species targeted now include Minimindi (Waterlily, Nymphaea macrosperma and N. violacea), Miwulngini (Red Lotus Lily, Nelumbo nucifera) and Midugu (Water Chestnut, Eleocharis dulcis). At this time, Mifutyen (Native Peanut,

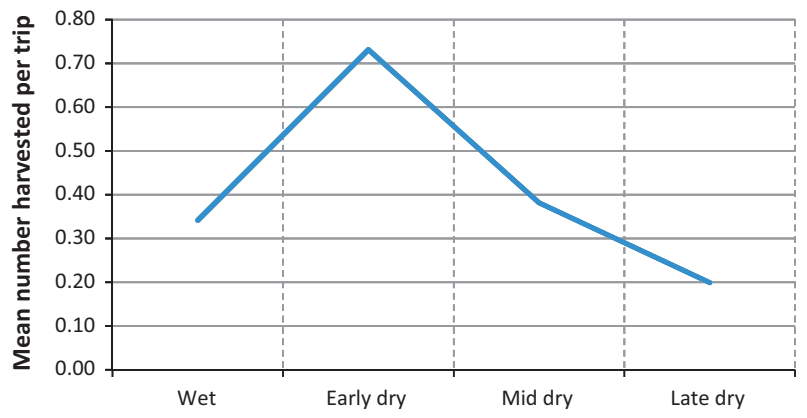

Figure 4. Seasonal Barramundi harvest by surveyed households in the Daly River, NT. 
Horsfieldia australianum), found in monsoon vine forests, and Mibuymadi (Bush Banana, Marsdenia viridiflora) are also collected. With the water levels lower, it is also much easier to collect Afurra (mussels, Velesunio sp.) and Amurriyi (crabs, Holthuisana sp.) on the edges of billabongs, creeks and springs. During this season, as the margins of billabongs become exposed with the drop in water level, turtle hunting begins.

Household surveys also show that harvesting activities in the Daly switch from use of the main river channel during the wet season to focus on billabongs as the dry season continues. By the Late Dry, $70 \%$ of all Daly River hunting trips are to billabongs. This is supported by the Ngan'gi Seasons calendar which observes that Malarrgu (Long-necked Turtle, Chelodina rugosa) hunting in billabongs intensifies over the Dry as water levels recede, exposing the muddy billabong margins. This soft mud will be searched with crowbars and feet in an attempt to find hibernating animals. The Late Dry seasons of Ngunguwe and Lirrimem are very hot and humid; there are mirages on the horizon, and the river water is warm. These seasons are known to be the best time for hunting Long-necked Turtle hiding under the mud. This seasonal harvesting knowledge is also reflected in the survey data with a distinct increase in harvesting rates for Longnecked Turtle between the Wet and Late Dry season survey periods (Fig. 5). During this very hot part of the year, the bark of the Yerrwurumbi (Ghost Gum, Eucalyptus alba) starts peeling, indicating that Adany (Bull Shark, Carcharchinus leucas) are fat and ready to catch. The river is really low now, and it is a good hunting time for Emelpe (Stingray, Dasyatis fluviorum) and Adetyerrwukume (Sawfish, Pristis microdon).

With the first rains of Kudede, Agadirr (Green Ant queens, Oecophylla smaragdina) are ready for eating and the turtles start moving after hibernating through the Dry. Turtles are said to still be fat at this time and still good hunting if you can find them. Turtles, like other aquatic species, are targeted for hunting by Indigenous research participants when they are known to be 'fat', with 'skinny' animals sometimes rejected and returned to the water. A preference for 'fatness' in bush resources among Aboriginal people has previously been documented, with the seasonal shifts in harvesting strategy often reflecting the degree of fat in the species concerned (Altman 1987; Rose 2000; Rouja et al. 2003).

\section{Discussion}

Combining quantitative household data and qualitative open ended interviews was found to offer a number of benefits in eliciting information on subsistence resource use. Household data obtained through repeat surveys provided a means of obtaining discrete data on resource use over a 2 year period. Interviews with Indigenous experts complimented those data by validating observations drawn from survey results. The seasonal calendar represents a system of resource management and production highly attuned to eco-hydrological relationships. The calendar makes these relationships explicit and reveals to others the cycle of eco-hydrological cues that signal to knowledgeable people when and what is available for harvesting. For

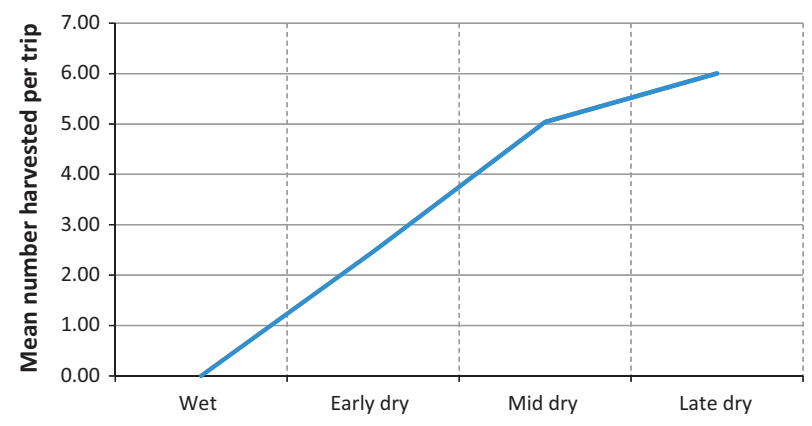

Figure 5. Seasonal Long-necked Turtle harvest by surveyed households in the Daly River, NT.

example, the flowering of Yeninggisyi (Red Kapok, Bombax ceiba) signals that Ewermisya (Freshwater Crocodile, Crocodylus jobnstoni) have laid their eggs. These eggs are then collected and eaten. Significantly, the Ngan'gi Seasons calendar reveals that Indigenous people take their cues from some ecological observations that fall outside the realm of orthodox scientific knowledge. For example, while Ngan'gi people know that the peeling of bark from the trunk of the Ghost Gum (Eucalyptus papuana) signals that Bull Sharks in the river are fat and ready to be hunted, ecologists looking for ecological linkages and drivers of ecosystem function are unlikely to arrive at such relationships. Relationships between observed phenomena could be increasingly informative if collaborative efforts continue, particularly in relation to synchronised system events that may be triggered by shared, high level, ecosystem drivers. It is possible that a clearer understanding of these synchronous events, and their potential for 'decoupling' under anthropogenic disturbance, can provide new insights and metrics for monitoring the impacts of environmental perturbations.

The resource-use patterns revealed in the quantitative data on species harvest rates and locations (Jackson et al. 2011) tell us much about what wild resources are being extracted, where and when, and this information is of considerable value to water resource planners (Finn \& Jackson 2011). However, analysed alone these data tells us little about the decisions people make in their subsistence strategies and the detailed ecological knowledge underpinning harvesting effort and success in hunting, gathering and fishing.

The Indigenous authors of the seasonal calendar are consistently observing localised seasonal changes and watching for indicators in the environment, ready to change their temporal and spatial harvesting patterns. Therefore, the calendar serves as a model of seasonal resource use that shows points in time when people change their harvesting behaviour and some of the socio-ecological reasons why behaviour has altered. Thus, the calendar reveals a continuous pattern of seasonal harvesting and resource use that is not discernible 
from household survey data collected periodically. The calendar provides a comprehensive inventory of resources used, including those species that are of interest and value but harvested infrequently. We found that a number of species referred to in the Ngan'gi Seasons calendar were not captured in the household surveys spanning a 2-year period. Relying on quantitative household surveys alone would miss those infrequently harvested species, pointing to the value of temporal continuity in documenting the qualitative information.

On the other hand, calendars also have limits as a sole source of information. The calendars we constructed in partnership with Indigenous knowledge holders do not reveal the quantities caught or effort expended. Return on effort is particularly important to know if one is interested in monitoring the availability of key resource species, as it allows the separation and identification of reductions in effort and reductions in harvest success. In addition, while the calendars provide information on the types of habitats targeted in different seasons, they do not provide data on locations visited, as the household surveys revealed. Spatially referenced data are important when attempting to predict the eco-hydrological impacts of increased water extraction on key sites of value including those of significant resource value.

Neither methodology sought to explicitly address the changing patterns of resource use over longer temporal scales. The recording of oral histories as a complementary component of the research revealed historical change in the sites used for fishing and hunting, as well as changing techniques and tools adopted in an effort to reduce effort and increase harvesting success. This historical context may be an important consideration when predicting potential impacts of a flow change into the future.

Documenting IEK in a participatory fashion provided an important social benefit beyond the contribution to public good research. The research activities promoted engagement and local participation, and the development of trust between the researchers and Indigenous participants, manifest in invitations to undertake other activities with the same groups and to develop further calendars with other groups. Over the course of the project numerous applied projects and methodologies emerged as Indigenous research participants voiced ideas, including the development of a participatory photography project (Photovoice) which involved several different community groups (see Wang \& Burris 1997 for methodology). The production of highly popular visual outputs (including seasonal calendars) under the direction of Indigenous experts was of great interest to both researchers and Indigenous community members, both parties curious about socio-ecological connections and the impacts of water-use decisions on valued relationships with country. A strong motivation of Indigenous participation was to promote and preserve 'culture', including language, and a desire to see the calendars used as a teaching and learning tool to pass information on to younger people in the respective communities and regions. The Ngan'gi Seasons calendar has been taken up by local schools and is viewed with great interest by members of the research community and wider Australian public.

\section{Conclusion}

A more complete picture of Indigenous resource-use and management strategies was provided by the adoption of mixed methods: quantitative household surveys and qualitative open ended interviews. While the household surveys provided discrete quantifiable data, the IEK compiled in the Ngan'gi Seasons calendar captured continuous resource-use patterns along the continuum of the cycle of the seasons and therefore, the more subtle behavioural changes that were not captured in the periodic resource harvest surveys.

Seasonal calendars reveal a body of knowledge about the relationship between people and the environment and underpin local NRM strategies. Although popular as a communication tool, calendars are, however, currently under-utilised in state-led NRM. The Ngan'gi Seasons calendar has informed the scientific understanding of patterns of resource use and relationships between people, subsistence use and river flows in the Daly River catchment. We recommend that natural resource managers, researchers and Indigenous experts prioritise collaborative projects that record Indigenous knowledge and apply the insights from cross-cultural exchange to environmental management challenges.

\section{Acknowledgements}

The authors would like to acknowledge the contributions of Indigenous traditional owners in the Daly River region, Northern Territory, in particular the Indigenous experts who contributed to the Ngan'gi Seasons calendar: Molly Yawulminy, Catherine Ariuu, Dorothy Daning, Kitty Kamarrama, Benigna Ngulfundi, Maureen Wurrumburr and Mercia Wawul. We thank Murray Radcliffe of the National Water Commission, Michael Douglas of Charles Darwin University, Jon Altman of the ANU, Sandy Toussaint of the UWA and Mark Kennard and Brad Pusey of Griffith University for their ongoing support for the research described here. TRaCK receives major funding for its research through the Australian Government's Commonwealth Environment Research Facilities initiative; the Australian Government's Raising National Water Standards Program; Land and Water Australia; the Fisheries Research and Development Corporation and the Queensland Government's Smart State Innovation Fund. The research reported here was reviewed and approved by the Charles Darwin University Human Research Ethics Committee and worked within the guidelines of a Northern Land Council research agreement

\section{References}

Altman J. C. (1987) Hunter-Gatherers Today: An Aboriginal Economy in North Australia. Australian Institute of Aboriginal Studies, Canberra

Baker R. (1999) Land is Life: From Bush to Town. The Story of the Yanyuwa People. Allen \& Unwin, Melbourne.

Berkes F. (1993) Traditional ecological knowledge in perspective. In: Traditional Ecological Knowledge: Concepts and Cases (ed. J. T. Inglis) pp. 1-9, UNESCO Canada/MAB, Ottawa.

Berkes F., Colding J. and Folke C. (2000) Rediscovery of traditional ecological knowledge as 
adaptive management. Ecological Applications 10, 1251-1262.

Bradley J. (2010) Singing Saltwater Country: Journey to the Songlines of Carpentaria. Allen \& Unwin, Sydney

Brimblecomb J. (2007) Enough for Rations and a Little Bit Extra: Challenges of Nutrition Improvement in an Aboriginal Community in North East Arnhem Land. Charles Darwin University, Darwin.

Buchanan G., Altman J., Arthur B. et al. (2009) "Always part of us": The Socioeconomics of Customary Use and Management of Dugong and Marine Turtles - A View from Bardi and Jawi Sea Country, Western Australia. Centre for Aboriginal Economic Policy Research, NAILSMA and Kimberley Land Council, Canberra.

Chase A. and Sutton P. (1981) Hunters and gatherers in a rich environment: Aboriginal coastal exploitation in Cape York Peninsula. In: Ecological Biogeography of Australia (ed. A Keast) pp. 1817-1852, Dr Junk, London.

Ens E., Cooke P., Nadjamerrek R. et al. (2010) Combining Aboriginal and non-Aboriginal knowledge to assess and manage feral water buffalo impacts on perennial freshwater springs of the Aboriginal-owned Arnhem Plateau, Australia. Environmental Management 47, 751-758.

Finn M. and Jackson S. (2011) Protecting Indigenous values in water management: a challenge to conventional environmental flow assessments. Ecosystems (Online First ${ }^{\mathrm{TM}}$ ), 14 1232-1248.

Fraser D. J., Coon T., Prince M. R. et al. (2006) Integrating traditional and evolutionary knowledge in biodiversity conservation: a population level case study. Ecology and Society 11, 1-14.

Goodall H. (2008) Riding the tide: Indigenous knowledge, history and water in a changing environment. Environment and History 14, 355-384.

Gray M. C., Altman J. C. and Halasz N. (2005) The Economic Value of Wild Resources to the Indigenous Community of the Wallis Lakes Catchment. Centre for Aboriginal Economic Policy Research, The Australian National University, Canberra.

Hill R., Grant C., Robinson C. et al. (In press) A governance typology of Indigenous engagement in environmental management. Ecology and Society.

Horstman M. and Wightman G. (2001) Karparti ecology: recognition of Aboriginal ecological knowledge and its application to management in North-Western Australia. Ecological Management \& Restoration 2, 99-109.

Huntington H. P. (2000) Using traditional ecological knowledge in science: methods and applications. Ecological Applications 10, 12701274.

Jackson S. and Altman J. (2009) Indigenous rights and water policy: perspectives from tropical northern Australia. Australian Indigenous Law Review 13, 27-48.

Jackson S. and O'Leary P. (2006) Indigenous Interests in Tropical Rivers: Research \& Management Issues; A Scoping Study for Land and Water Australia's Tropical Rivers Program prepared for the North Australian Indigenous Land and Sea Management Alliance (NAILSMA). CSIRO Sustainable Ecosystems, Darwin. Jackson S., Finn M., Woodward E. et al. (2011) Indigenous Socio-Economic Values and River Flows. Tropical Rivers and Coastal Knowledge \& CSIRO, Darwin.

Kennard M. J., Pusey B. J., Olden J. D. et al. (2010) Classification of natural flow regimes in Australia to support environmental flow management. Freshwater Biology 55, 171193.

Langton M. (1998) Burning Questions: Emerging Environmental Issues for Indigenous Peoples in Northern Australia. Centre for Indigenous Natural and Cultural Resource Management, Darwin.

Lantz T. C. and Turner N. J. (2003) Traditional phenological knowledge of Aboriginal peoples in British Columbia. Journal of Ethnobiology 23 263-286.

Luckert M. K., Campbell B. M., Gorman J. T. et al. (eds) (2007) Investing in Indigenous Natural Resource Management. Charles Darwin University Press, Darwin.

Marrfurra P., Akanburru M., Wawul M. et al. (1995) Ngan'gikurunggurr and Ngan'giwumirri Ethnobotany: Aboriginal Plant Use From the Daly River Area, Northern Australia. Conservation Commission of the Northern Territory, Darwin.

Meehan B. (1981) Wetland hunters: some reflections. In: Monsoonal Australia: Landscape, Ecology and Man in the Northern Lowlands (eds C. Haynes, M. Ridpath and M. Williams) pp. 197-206, A.A. Balkema, Rotterdam.

Natural Resource Management Ministerial Council (2010) Australia's Biodiversity Conservation Strategy 2010-2030. Department of Sustainability, Environment, Water, Population and Communities, Canberra.

Neate G. (2002) Reconciliation on the ground: meeting the challenges of native title mediation-Part 1. ADR Bulletin. 5(6), Article 1. Available from URL: http://epublications.bond.edu.au/adr/vol5/iss6/1/.

Petheram C., McMahon T. and Peel M. (2008) Flow characteristics of rivers in northern Australia: implications for development. Journal of Hydrology 357, 93-111.

Prober S. M., O'Connor M. H. and Walsh F. J. (2011) Potential basis for shared understanding in environmental management. Ecology and Society 16, Available from URL: http:// www.ecologyandsociety.org/vol16/iss12/art12/.

Reid N. and Marrfurra McTaggart P. (2008) Ngan'gi Dictionary. Australian Linguistics Press, Armidale.
Rose F. (1987) The Traditional Mode of Production of the Australian Aborigines. Angus and Robertson, Sydney.

Rose D. B. (1996) Nourishing Terrains: Australian Aboriginal Views of Landscape and Wilderness. Australian Heritage Commission, Canberra.

Rose D. B. (2000) Dingo Makes us Human: Life and Land in an Australian Aboriginal Culture. Cambridge University Press, Oakleigh.

Rouja P. M., Dewailly E., Blanchet C. et al. (2003) Fat, fishing patterns and health among the Bardi people of north Western Australia. Lipids 38, 399-405.

Russell-Smith J., Lucas D., Gapindi M. et al. (1997) Aboriginal resource utilization and fire management practice in western Arnhem Land, monsoonal northern Australia: notes for prehistory, lessons for the future. Human Ecology 25, 159-195.

Toussaint S., Sullivan P. and Yu S. (2005) Water ways in Aboriginal Australia: an interconnected analysis. Anthropological Forum 15, 61-74.

Turner N. J. and Clifton H. (2009) 'It's so different today': climate change and indigenous lifeways in British Columbia, Canada. Global Environmental Change 19, 180-190.

Venn T. J. and Quiggin J. (2007) Accommodating indigenous cultural heritage values in resource assessment: Cape York Peninsula and the Murray-Darling Basin, Australia. Ecological Economics 61, 334-344.

Walsh F. (1990) An ecological study of traditional Aboriginal use of 'country': Martu in the Great and Little Sandy Deserts, Western Australia. Proceedings of the Ecological Society of Australia 16, 23-37.

Wang C. and Burris M. (1997) Photovoice: concept, methodology, and use for participatory needs assessment. Health Education and Behavior 24, 369-387.

Weir J. (2010) Murray River Country: An Ecological Dialogue with Traditional Owners. Aboriginal Studies Press, Canberra.

Woodward E. (2010) Creating the Ngan'gi Seasons calendar: reflections on engaging Indigenous knowledge authorities in research. Learning Communities: International Journal of Learning in Social Contexts 2, 125137.

Yingguny Lindsay B., Waliwararra K., Miljat F. et al. (2001) Malakmalak and Matngala Plants and Animals: Aboriginal Flora and Fauna Knowledge from the Daly River Area, Northern Australia. Parks and Wildlife Commission of the Northern Territory, Darwin.

Yu S. (2003) Ngapa Kunangkul (Living Water): an indigenous view of groundwater. In: Country: Visions of Land and People in Western Australia. (eds A. Gaynor, A. Haebich and M. Trinca) pp. 33-55. WA Museum, Perth. 